Dieses Dokument ist eine Zweitveröffentlichung (Verlagsversion) / This is a self-archiving document (published version):

Stefan Horlacher

"Slightly Quixotic": Comic Strategies, Sexual Role Stereotyping and the Functionalization of Femininity in David Lodge's Trilogy of Campus Novels under Special Consideration of Nice Work (1988).

Erstveröffentlichung in / First published in:

Anglia. Journal of English Philology. 2007, 125(3), S. 465-483. ISSN 0340-5222.

DOI: https://doi.org/10.1515/ANGL.2007.465

Diese Version ist verfügbar / This version is available on:

https://nbn-resolving.org/urn:nbn:de:bsz:14-qucosa2-364175 
Stefan Horlacher:

"'Slightly Quixotic': Comic Strategies, Sexual Role Stereotyping and the Functionalization of Femininity in David Lodge's Trilogy of Campus Novels under Special Consideration of Nice Work (1988)." Anglia 125.3 (2007): 465-483. 


\title{
“SLIGHTLY QUIXOTIC”: COMIC STRATEGIES, SEXUAL ROLE STEREOTYPING AND THE FUNCTIONALIZATION OF FEMININITY IN DAVID LODGE'S TRILOGY OF CAMPUS NOVELS UNDER SPECIAL CONSIDERATION OF NICE WORK (1988)
}

\begin{abstract}
In view of the fact that David Lodge's campus novels are renowned for their ability to make light of traditional gender stereotypes as well as for their purportedly liberal, pro-feminist, intertexual, dialogical and metatextual dimensions, this article seeks to explore more precisely the strategic and unavowedly political functions humour and the comic fulfil in Changing Places, Small World and Nice Work. What will be demonstrated is that Lodge's light-hearted, tolerant and at times even progressive liberalism is little more than an effect produced by the textual surface structure. In the case of Nice Work, this discrepancy between the surface and the deep structure leads to the paradox that while voyeuristic structures and male bonding are overtly ridiculed, on a deep structural level they are effectively reaffirmed. Though Lodge's novels are at the level of their surface structure sustained by a logic which uses the "comic mode" as a more or less subtle form to critique traditional gender stereotypes, literary conventions, the British university system and British industry, ultimately his 'Rummidge trilogy' reinforces an aesthetically, morally and politically conservative subtext.
\end{abstract}

Nice Work (NW), the third sequel of Lodge's famous trilogy of campus novels, has not only won the Sunday Express Book of the Year Award and been shortlisted for the Booker Prize, it has also been called "a work of immense intelligence" (Anthony Burgess), "a feast of fun" (Kingsley Amis), and "rich in reserves of humour and irony" (Mail on Sunday). ${ }^{1}$ And no matter whether we consider the mildly satirical trans-Atlantic romp Changing Places $(C P)$, the satirico-romanesque, carnivalesque and (meta-)meta-fictional (Wolf 1992, 26) Small World (SW) or the satirico-parodistical and almost theoretical Nice Work (cf. Lerner 1988, 38), all of these novels share a "comic mode" which, so Lodge, offers "a way of reconciling a contradiction [...] between my critical admiration for the great modernist writers, and my creative practice, formed by the neo-realist, anti-modernist writing of the 1950s" ("An Afterword", 170). Moreover, as will become clear, Lodge's campus novels all share a kind of humour that subtly and implicitly draws their readers into an often voyeuristic complicity with the male narrator. Therefore a closer examination of Nice Work in particular prom-

1 Blurbs on the cover of the Penguin Edition 1989. 
ises to reveal a hitherto largely neglected 'darker side' to that novel as well as to the other two in Lodge's well-known trilogy of campus novels.

In order to analyse how - significantly mostly female - gender identities are subverted and denigrated through laughter and the comic in Lodge's novels, I propose a) to demonstrate that one of the main mechanisms which Lodge's novels use in order to create laughter is the functionalization of gender stereotypes and b) to ask whether this is primarily a creative or rather a conservative and ultimately sexist textual strategy. If a joke does not "come about unintentionally" (Freud), if therefore "we must try to discover the intention underlying the construction of the joke" and if - in addition to this - we consider Roland Barthes' and Michel Fouault's work on the notion of the author, then it becomes evident that there is absolutely no need to speculate about Lodge's intentions in writing his comic novels but that it is all the more important to ask what strategic and possibly unavowedly political functions humour and the comic fulfil in these texts. Freud has argued that we "are inclined to give the thought the benefit of what has pleased us in the form of the joke", so that we "are no longer inclined to find anything wrong that has given us enjoyment and so to spoil the source of a pleasure" $(1960,162)$. From this it follows that to "perceive a situation as humorous causes it to appear less discriminatory, and more acceptable" (Bill and Naus 1992, 659). However, if sexism "disguised by and delivered through humor" is potentially interpreted "as being harmless and innocent", and thus tends to escape criticism altogether (646), if "[p]erceiving and labeling an incident as humorous appears to diminish its sexist content" (660), the questions arise whether this is not exactly the mechanism which underlies Nice Work and whether Lodge does not use the "comic mode" to hide sexist if not misogynist tendencies in his novels. A similar mechanism in the sense of a potential contradiction between a supposedly funny or even hilarious surface level of the text and a probably sexist subtext can be observed when we inquire a) whether in Lodge's campus novels 'conservative' comic realism does not tend to masquerade as an open and non-deterministic post-modernism (cf. Björk 1993; Eagleton 1988), b) whether Lodge's "layered fiction" (Lodge in: Haffenden 1985, 160) does not offer the reader a conservative officially sanctioned ritual dressed up as subversive Bahktinian carnival (cf. Björk 1993, $89 \mathrm{ff.}$.) and c) whether and to what extent Lodge's texts - and especially Nice Work - use humorous, even hilarious, but in reality clearly obsolete sex role models in order to satirize and finally to sacrifice 'female identity' at the altar of a patriarchal, liberal humanist social system.

Finally, I shall consider in how far Nice Work deconstructs itself by a mechanism which the text ostentatiously displays on the level of the histoire but which it finally cannot control, the question being whether some of the most important mechanisms for the creation of comic effects in Lodge's novels, namely voyeurism, stereotyping and the instrumentalisation of the feminine, 
can be shown to be part of a continually disavowed textual deep-structure, thereby revealing a surprisingly conservative capitalist logic, strictly in accordance with Victor Wilcox's doctrine of "Who pays?" (NW, 116).

\section{Nice Work, the Motif of the 'Two Cultures' AND THE Use OF STEREOTYPeS}

Critics generally agree that Nice Work is an intelligently conceived and humorously executed blend of the campus and industrial or 'Condition of England' novel. However, if in Benjamin Disraeli's Sybil, or the Two Nations these two nations are meant to be the rich and the poor who are "as ignorant of each other's habits, thoughts and feelings, as if they were [...] inhabitants of different planets" and if Elizabeth Gaskell's North and South deals with the contrast between a southern, rural and a northern, industrialist England, Nice Work incorporates these oppositions but complements them with the counter-poles of masculinity versus femininity, students versus workers and real life versus theory. This blend of campus and industrial novel has as one of its effects that the central opposition of town versus gown undergoes a process of triangulization, becoming university versus society versus industry, while the seemingly homogeneous university pole is itself divided into a liberal-humanist and a feminist-poststructuralist camp. ${ }^{2}$

As part of a university meets industry 'shadow scheme' and in order to increase mutual understanding, Robyn Penrose, a poststructuralist and feminist university teacher, has to go once a week to visit Victor Wilcox's iron-casting factory which is situated in a dark industrial no-man's-land. By means of this plot device, the novel makes use of the famous motif of the 'two cultures' on at least three different levels, namely a) sexually: in that the radical Dr Robyn Penrose - she is female despite her significantly androgynous name - is confronted with the conservative 'self-made man' Victor Wilcox who describes himself as a "phallic sort of bloke" (NW, 291); b) culturally: in that Robyn, an expert on the Victorian industrial novel, is forced to leave her ivory tower and confront the reality of British industry in the 1980s; c) intertextually: in that Nice Work explicitly and implicitly imports plot structures from North and South and programmatically endeavours to save not only British industry but also the British university system by championing E. M. Forster's slogan "Only connect".

A closer look at the main characters reveals that already the name of Lodge's male protagonist Vic Wilcox simultaneously evokes victory, "will and cock" (Lodge, The Art of Fiction, 38) as well as Henry Wilcox from

2 Its counter-pole, business, is equally divided, namely into the traditional industrial manufacturing sector and the post-industrial service sector of the London stock market. 
Howards End and Victorian notions of sexuality and virtue. Terry Eagleton (1988) has called Victor "truculent, philistine" and "averagely sexist" (98), and indeed, Lodge's protagonist distrusts his wife and his daughter and can neither talk about sexuality nor the body $(N W, 22)$. Victor's motto is “All I'm fit for is work", he sees himself as "the captain of a sleeping ship, alone at the helm, steering his oblivious crew [i.e. his family] through dangerous seas" and he "feels as if he is the only man awake in the entire world" (NW, 14). As a character, Victor is presented by the narrator from a sympathetic perspective which consists of "a mixture of direct narrative and an unmediated stream-of-consciousness technique" (Björk 1993, 115). If the narrator is critical of Victor, for example by making fun of his fantasy of omnipotence, Victor's numerous character flaws nevertheless serve to make him more human and likeable. He is married to Marjorie, the marriage is boring and unhappy, and the narrator repeatedly uses this fact to make a laughing stock, but not of Victor but of his wife (NW, $13 \mathrm{f}$.). Marjorie is described as "softhearted or softheaded", as a member of Weight Watchers and as dependent on Valium. Having given up any significant life of her own, she is a mere appendage, responsible for the family but hardly being able to think by herself. Victor as well as the narrator see Marjorie mainly "as a body [...] and as a function of the home, but not as an individual" (Wennö 2000, 26). Although there is neither sexual nor mental intercourse in this marriage, the text repeatedly - and tellingly - shies away from asking why this is the case.

Marjorie is - of course - not the only housewife in Lodge's campus novels. In her prudishness, she shares some essential qualities with Philip Swallow's wife Hilary, who in Changing Places is introduced as a woman "looking rather like a brown bear emerging from hibernation" $(C P, 85)$. When, about 150 pages later, the experienced womanizer Morris Zapp and Hilary end up in bed together, the joke is again on Hilary, namely on her lack of what the text calls a sophisticated sexuality $(C P, 230)$. But if Hilary Swallow is at least allowed some sexuality in Lodge's first campus novel, this changes radically in his next book. After Philip Swallow has left her for a passionate affaire with Joy Simpson, he finally returns to his wife because "Philip decided he was getting to the age when he needed a mother more than a mistress" (SW, 359). The first laugh here may be at the expense of Philip, who feels too old for Joy, in the double sense of the word, and therefore goes back to his wife. The second laugh, however, is definitely at the expense of the housewife, namely on Hilary, who is the very opposite of Joy and whose femininity and sexuality is reduced to the qualities of a mother, that "strange fold that changes culture into nature, the speaking into biology" (Kristeva 1986, 182). ${ }^{3}$ Indeed, it is striking how of-

3 "And as for Hilary, well, he found it difficult after all these years to think of her as ontologically distinct from her offspring" (CP, 25; cf. Irigaray 1974, 13, 61 f.; Irigaray 1977, $29 \mathrm{f}$.$) .$ 
ten Lodge's narrator characterizes his female protagonists by describing not their minds but their bodies, and preferably their breasts. One has only to compare the narrator's description of Robyn's "round breasts with pink, pointed nipples" (NW, 291) to the description of Marjorie's breasts which are characterized by the "dark circles round her flat nipples [which showed through the thin material] like two stains" (NW, 163).

In stark contrast to Lodge's traditional housewives such as Marjorie or Hilary, Dr Robyn Penrose is presented as someone neither Wilcox nor the narrator can understand. Right from the start, the narrative discourse creates a distance between Robyn and the reader, who is never in a position to enter her thoughts. Robyn remains hermetic, is not allowed to arouse our sympathies; and if she is allowed to explain her (theoretical) position, this is immediately criticized by the supposedly well-meaning 'authorial' narrator. As Eagleton (1988) argues, Robyn "is much of the time [...] made to speak like a theoretical textbook, spouting indigestible chunks of Lacan" (99), and Mary Jo Salter states that "Lodge has been clever in fleshing out the tacky capitalist Vic as a sympathetic and idiosyncratic man, while leaving Robyn Penrose mostly as a type - risen, as her surname suggests, from the pen" $(1989,46)$. Since Robyn's Christian name is ambiguous as far as her sex is concerned, Wilcox and his colleagues are in for a surprise when the Shadow Scheme starts, given that they expect a man instead of a trendy lefty feminist "woman lecturer in English Literature" (NW, 107). But as if to compensate for Victor's disappointment, Nice Work insidiously suggests that as a feminist, Robyn must possess what is traditionally considered to be male attributes: she is characterized as competitive, as "more enthusiastic, more energetic, more productive" $(N W, 52)$ than her male colleagues, has a "reputation in the family for being strong-willed [and] bossy" (NW, 55) and her household, if we trust Victor, consists of an "incredible litter of books and dirty coffee cups and wineglasses and album sleeves and copies of Spare Rib and Marxism Today" (NW, 166). Whether at university or with her gentle on-and-off lover Charles, the text 'forces' Robyn to adopt a male subject position and thus discursively situates her within the literary tradition of the New Woman.

Although Lodge claims in an interview that as a result of feminism women have become "less submissive to social stereotyping" (Lodge, "Thinking about Women”, 615), his campus novels in fact prove the exact opposite, voicing prejudices characteristic of the Victorians. The latter assumed that "higher education turns women into militant bluestockings, unsuited for marriage and family life" (Björk 1993, 120), and it is in this vein that Lodge states in The Art of Fiction: "An androgynous name seemed highly appropriate to my feminist and assertive heroine" (38). All brains and no sex, one could say, or, to quote $19^{\text {th }}$-century medical discourse: "[I]f women expended their energies on higher education, they must expect to find their reproductive abilities stunted, if not destroyed [...]. 'When $\mathrm{Na}$ - 
ture spends in one direction, she must economise in another direction'” (Mallet 1989, 215). Thus, it is no surprise that Robyn often talks about but hardly ever has sex and that Victor can imagine her only as single and chaste. If the narrator explicitly states that "What was left was sex in the head" (NW, 56), then the allusion is to D. H. Lawrence, whose poem Leave Sex Alone argues that "For while we have sex in the mind, we truly have none in the body".

In both Lawrence and Lodge the result of this 'perversion' seems to be that feminists are potential lesbians, or at least have lesbian friends. They are mostly flat-breasted sexless virgins or spinsters whose problems would be solved, if only they married. One could almost say that Nice Work is still heeding the advice given to unmarried female teachers in the 1932-issue of The Journal of Education, namely "what they really need is marriage, a home and family" (cf. Björk 1993, 125). As a matter of fact, Nice Work slyly suggests that every woman, no matter how independent she may be, is in reality in need of a man $(N W, 322)$. And if there are no men for these 'strong women', what they regularly do in a Lodge novel is to masturbate: in Small World Morris Zapp's ex-wife Desirée “wonders whether to try and relax with the help of her vibrator" $(S W, 98)$, and in Nice Work the narrator tells us about Robyn:

And if her body occasionally craved a keener sensation, she was able to provide it herself, without shame or guilt, theoretically justified by the writings of radical French feminists like Hélène Cixous and Luce Irigaray, who were very eloquent on the joys of female auto-eroticism. $(\mathrm{NW}, 57)$

This raises the following questions: Why does Nice Work construct this obviously outdated Lawrentian image of the sexless female brain called Robyn Penrose? Why does Robyn have to justify her desire by recourse to feminist theory? And why does the text undermine Robyn's independence and even negate her desire?

It is clear that Robyn's theoretical premises and her knowledge about literary theory are too powerful for either Victor Wilcox or Philip Swallow to challenge successfully. In addition to this, Robyn simultaneously inspires fear and desire and thoroughly fascinates poor Victor Wilcox. But - and this is typical for Changing Places and Small World as well - sexuality with a strong, self-confident and intellectual woman remains highly problematic, even if Nice Work repeatedly makes fun of a supposed male superiority. This interesting feature, that traditional notions of a phallic maleness are ridiculed but defended whenever they come under real threat, is typical of most of Lodge's fiction as prove the very few 'strong women' present in his campus novels, such as Fulvia Morgana, the marxist cultural studies professor, or Desirée Byrd, the redhaired ex-wife of Morris Zapp and successful feminist writer with notoriously sado-masochistic inclinations ( $S W$, 153). Again and again, strong women are presented as wearing "high boots 
with spurs", as sexual predators with sadistic tendencies and - alluding to Morgan le Fey as well as to John Fowles' Sarah Woodruff - as dangerous witches who threaten not only poor Catholic young men but also grown up machos like Morris Zapp, who, having been tied up, scratched and bitten, sheepishly beats a retreat when Fulvia Morgana invites her husband to join them in a ménage à trois (NW, $152 \mathrm{f}$.).

\section{The Subjugation and Domestication of Femininity}

Since the concept of an independent and self-confident female usually evokes in Lodge's novels the stereotype of the sadistic redhead, of the witch and of the castrating woman, Nice Work adopts a strategy analogous to that of the traditional Bildungsroman (cf. Horlacher 2006, 243f.) and stages the development of Robyn from sexless independency towards a docile and patriarchally controlled form of sexuality. But how is this incarnation of the male fantasy of a predatory and for this very reason attractive woman to be humanized? How does one 'control and subjugate' a feminist and initiate her into what D. H. Lawrence would call "true womanhood"? What Lodge's supposedly funny and hilarious text demands, is nothing less than the symbolic castration of the phallic woman, its willing instruments being the narrator as well as Victor Wilcox, the well-intentioned "phallic sort of bloke" (NW, 291); and what Lodge's text does to achieve this 'hostile takeover', to use the logic of capitalism which Nice Work so strongly favours, is to adopt a double strategy involving the narrative instance as well as the plot structure.

The reason why the reader is not allowed to enter Robyn's mind does not reside in the fact that the narrator wants to preserve a kind of feminine integrity. On the contrary, Robyn is kept at a distance in order to prevent any readerly sympathies. When the narrator states that his heroine is a "character who, rather awkwardly for me, doesn't herself believe in the concept of character" (NW, 39) and if Robyn repeatedly refuses this concept as inadequate and ideologically fraught, it is clear that the narrator is denouncing Robyn's theoretical stance as a mask of abstractions which does not work in 'real life', which is riddled with contradictions (cf. Antor 1996, $667 \mathrm{ff} ., 688 \mathrm{ff}$.) and which his 'male common sense' may safely ignore. Although Robyn makes it explicitly clear that she does not want to be perceived as a sexual object, she is then reified by a self-confidently patronising narrator who seems to understand her better than she understands herself. ${ }^{4}$ If the narrator concludes: "I shall [...] take the liberty of treating her

4 If Robyn "generally favours loose dark clothes, made of natural fibres, that do not make her body into an object of sexual attention" (NW, 49), she does so, if we trust the narrator, not for environmental or feminist reasons but mainly because 
as a character" (NW, 41; cf. Kühn 1992, 175), a feminist reading might well argue that Robyn and her convictions are radically ignored, not to say 'raped' by the narrative discourse throughout the text, that she is turned into an object and "colonized by an ironic narrator with narrow views of the minds of 'liberated' women" (Björk 1993, 69).

It is no surprise then that Victor's foundry, which Robyn has to visit as part of the Shadow Scheme, is situated on the "dark side of Rummidge, as foreign to her [Robyn] as the dark side of the moon" (NW, 96). This cultural Heart of Darkness alludes to Marlow's traumatic journey through the African wilderness and signifies a regression from civilisation to something more primitive, in Robyn's case from the insulating world of theories and texts to the needs and desires of the body. In other words, it is high time that Robyn learns that Derrida's il n'y pas de hors-texte does not stand the test of reality: the 'disembodied' feminist critic gradually becomes more and more sexualized by a narrative discourse which finally turns her into the passive object of the male gaze, as for example when she is stared at by Victor like an animal in a zoo (NW, 108), when she is compared to "a Greek goddess and a lot of nymphs washing themselves in a pond in the middle of a wood" $(N W, 226)$ or when she is presented naked in a typically impressionist pose which - as the narrator informs us - she would energetically reject $(N W, 44)$.

In Robyn's case, her sexual instrumentalisation goes so far that Victor already early on not only gets "a glimpse of [...] [her] gently sloping breast and the profile of a pink nipple" (NW, 166), but that he also uses this impression in bed with his wife Marjorie in order to achieve an orgasm: "he was only able to come by imagining he was doing it to Robyn Penrose" (NW, 166). But Victor not only 'uses' his visual memory of Robyn, he also imagines her "stark naked, her bush as fiery red as her topknot" ${ }^{5}$ NW, 166) and almost rapes her in his fantasy, imagining her as "thrashing and writhing underneath him [...], moaning with pleasure in spite of herself as he thrust and thrust and thrust" (NW, 166f.). ${ }^{6}$ Given that the novel stages these voyeuristic elements on the level of the histoire, one has to concede that Lodge at least implicitly and sometimes even explicitly denounces them. The same applies to Victor's double moral standard, since more than once, Nice Work pokes fun at Victor's position as a Peeping Tom (NW, $108 \mathrm{f}$.). But if Nice Work knowingly presents voyeuristic structures in order to achieve comic effects, if laughter arises not only because of the feminine object of the male gaze but also because of the voyeur, and if Lodge's text

this kind of clothing "disguises her smallish breasts and widish hips while making the most of her height" (NW, 49). See also NW, 44.

5 Lodge's novels do, of course, not offer any comparable descriptions of naked men.

6 Not only in this case can Victor be regarded as a projection of the narrative instance at the level of the diegesis. 
is self-consciously ironic, this does not prevent the novel from being caught in its own net. Peter Widdowson argues that " $[\mathrm{t}]$ here is a kind of noseagainst-the-window fascination with sex [...] about all of Lodge's fiction" $(1984,26)$, and indeed, the fact that Nice Work makes explicitly fun of sexism and voyeurism on the level of the histoire does not save the text on a subtextual level from falling prey to exactly the kind of logic it seems to denounce: the mise-en-scène of voyeurism on the level of the histoire can be seen as an unintentional mise-en-abime of the central mechanism of the text itself, given that Lodge's novel needs these structures in order to control and dominate femininity. If the stereotyping and castration of the phallic woman is one part of this logic, the reintegration of Robyn into a patriarchal and capitalist system as well as the ridiculing of her theoretical beliefs is another. From this perspective, the designation of her temporary job at Rummidge University as "Dean's Relief", Robyn's misinterpretation of "semen" for "Siemens" $(N W, 278)$ and the facts that she becomes Victor's secretary and bedfellow gain additional importance. What Robyn and the reader learn in Wilcox's outdated foundry as well as at the Frankfurt machine-tool fair with its highly symbolic "oiled pistons [which] slid up and down, in and out" (NW, 275), is that Robyn, this 'naïve redhead', who is so heavily influenced by 'nonsensical' French theory, has never before been confronted with 'real life'. And 'real life', of course, equals 'male life' as symbolized by Wilcox's hell-like phallic foundry with its "steely reptile devouring its prey or copulating with a passive mate" (NW, 125).

But if Victor Wilcox puts an end to Robyn's theory of "non-penetrative sex", it must, of course, be Robyn who seduces him. What Lodge in an interview has called "emancipatory" is in effect yet another badly disguised male fantasy, since on a subtextual level Robyn is the passive victim of a textual logic which not only prepares but even announces the seduction scene 26 pages before it actually occurs in the novel: "It was, perhaps, inevitable that Victor Wilcox and Robyn Penrose would end up in bed together" (NW, 267). Of course it was inevitable, but certainly less so for Robyn, who never really fancies Wilcox, than for the logic underlying Lodge's novel. As a matter of fact, the manipulative structures are evident: at the Frankfurt machine-tool fair, the novel makes Robyn play the role of Victor's secretary, and secretaries, according to Lodge, are most of the time weak-minded but excellent sexual playmates. Thus, Robyn avoids "giving any impression of suspicious intelligence" (NW, 277) and pretends "to be Vic's dumb bimbo" (Lodge, “Adapting Nice Work for Television”, 196), his "mistress, his dolly-bird, his bit of spare [...] thinly disguised as his secretary or PA" (NW, 270). At that point in time, Victor has already "stripped her of her doctorate" (NW, 275). In order to now escape the enactment of Victor's rape-fantasies discussed earlier on, the text resorts to two strategies: firstly, Robyn's - of course - lesbian friend Penny attributes these fantasies not to Victor but to Robyn herself: 
I think the idea of this man's power and money is a turn-on for you. He's the antithesis of everything you stand for. [...] I'm afraid it's the old female rape-fantasy rearing its ugly head again, Robyn. When Wilcox screwed you, it was like the factory ravished the university. (NW, 295)

Secondly, if industry really ravishes university and if - as part of this scheme - Victor is allowed to realize his fantasies of extramarital sexual intercourse with Robyn, the text turns the table on Robyn and makes her take the initiative: "she is not anxious. She is in control. Perhaps she feels a certain sense of triumph at her conquest: the captain of industry at the feet of the feminist literary critic - a pleasing tableau" (NW, 289; cf. 292). This alleged feminine dominance, however, is only a ploy and does not save the text from its own voyeuristic structures, i.e. from the male gaze which is neither made fun of nor - not even on a meta-level - critically commented on but simply reappears again and again: "Small, round breasts with pink, pointed nipples. A slender waist, broad hips, and gently curving belly. A tongue of fire at her crotch" $(N W, 291)$. Robyn is not only perceived as a sexual object, she is also forced to realize that she is perceived as such:

Wolf-whistles and catcalls [...] followed her as she hurried through the factory. The more the men whistled, the more ribald their remarks, the faster she walked; but the faster she walked, the more of a sexual object, or sexual quarry, she became $[\ldots]$ stumbling over piles of metal parts, skidding on the oily floor, her cheeks as red as her hair, the wings of her nostrils white, her eyes fixed steadfastly ahead, refusing to meet the gaze of her tormentors. (NW, $145 \mathrm{f}$.)

However, with the exception of Robyn and maybe Desirée Byrd, it seems to be quite natural for Lodge's novels that women find it gratifying to be regarded as objects of desire. One has only to think of Small World when Philip Swallow, "his beard brushing Joy Simpson's belly", makes "a wry joke about the silver among the gold, conscious of the contrast between her beautiful, still youthful body and his scraggy, middle-aged one", only to be reassured by his young lover with the words: "You make me feel desirable, that's what matters" (SW, 256; cf. Björk 1993, 69). If Lacan argues that desire desires the desire of the O/other (cf. Borch-Jacobson 1994, 197-239), Lodge's version of this is that female fulfilment in life depends on the desiring, one could also say lecherous, male gaze turning the female subject into an object and thereby providing it with a raison d'être which it gladly embraces.

If desire can function as "a subversive force, traversing the 'artifice' of social distinctions" (Eagleton 1988, 98), it can hardly provide that transcendence of social barriers in Nice Work. Quite the contrary: after the Frankfurt episode, Robyn throws Victor's numerous love letters away without even looking at them - and this denial of communication and "brusque refusal of her poignantly love-struck suitor is made to count against her, showing her up as callous and even frivolous" (Eagleton 1988, 100). Just 
as in Changing Places and Small World, the exploration of adultery, which in itself could be considered as transgressive, leads to a renewed commitment to marriage (Björk 1993, 104; Widdowson 1984, 23f.) with the Wilcoxes becoming "a perfect example of neoculturation" (Wennö 2000, 27) and Marjorie being presented as the ultimate winner of this inner familial development. The fact that she finds a new meaning and fulfilment in life by becoming Victor's secretary reveals a logic which considers a job as a secretary or typist as the fulfilment of female dreams - but how secretaries are rated by the narrator has been shown earlier on, namely as sexual playmates who are unable to give even the slightest "impression of [...] intelligence" (NW, 277). What is even more revealing of the ideological subtext of Nice Work is that Marjorie is kept uninformed of Victor's adultery which the novel neither morally nor symbolically condemns. Quite the opposite is the case; in order to hide Victor's affair with Robyn, lies are not only acceptable but even considered to be an ethical solution: Victor "was tempted to tell her the truth. But the least her loyalty deserved [...] was a merciful lie" (NW, 370). ${ }^{7}$ It would be interesting but certainly out of place here to speculate about the 'evolution' of Lodge's relationship to Catholicism (cf. Ommundsen 1990; Wolf 1992; Salter 1989), so often predominant in his early novels. Suffice it to say that Marjorie does not need to know since what really matters for Lodge is that the rules of society with marriage as its central social and economic institution remain intact.

\section{The Feminist Critic Caught in Her Own (Discursive) Net}

Marjory is not the only 'winner' in Nice Work who in reality pays a high price. Robyn is treated similarly when the narrator portrays the feminist critic, whose profession is so closely tied to discourse analysis, as reading feminist articles "with the kind of pure, trance-like attention that she used to give, as a child, to the stories of Enid Blyton" (NW, 47). As Björk notes, "[a] discourse fabricated by the feminist other, Lodge seems to be saying, alienates Robyn from her true self, threatening to confine her to a passive, trance-like condition" (123). Although Robyn is aware of the power of the discourses that surround her, she is utterly unable to realize that she is being 'manipulated' herself. "[T]he truly determined subject is he who is not aware of the discursive formations that determine him. Or her" (NW 40), Robyn confides, thereby "indicating that she, at least, is in control of her

7 "Marriage is the pillar on which society rests, a guarantee for social order and the perpetuation of the structure of bourgeois society. Adultery in this context becomes too threatening to be granted the status of actuality. Treated as a temporarily and spatially restricted experience, of which the 'wronged party' is kept uninformed, it is rendered harmless" (Björk 1993, 105). 
own mind and life" (Björk 1993, 121). ${ }^{8}$ As we have already seen, the narration suggests that the exact opposite is true, so that for Robyn feminist discourse not only functions similarly to Mikhail Bahktin's "authoritative word" but she herself also fails where Margaret Hale or Margaret Schlegel manage to connect the prose with the passion, i. e. to transgress boundaries.

While Robyn's literary precursors were to a certain degree able to free themselves from dominant discourses, Robyn does the opposite and rigorously sticks to the stereotype of the independent woman, characterizing her love-making with Victor as "just a fuck, nothing more or less" (NW, 301). And as a matter of fact, Lodge's feminist academic, who, albeit in another context, calls her own behaviour "slightly Quixotic" is not even allowed to understand that at least in part she copies and acts out exactly the literary models which she so eloquently condemns in Victorian literature. If Robyn's literary precursor Margaret Hale first takes against the self-made mill owner John Thornton, then sides with him against his workforce, reforms him, and becomes his lover, and if Robyn argues that the women writers of industrial novels were fascinated by a "male sexuality of a dominating and destructive kind" (NW, 78; cf. 295), this is exactly the kind of behaviour and of sexuality the supposedly frigid feminist critic falls prey to. The narrator, of course, does not hesitate to make clear that Robyn falls short of her own premises (NW, 107). If in Howards End as well as in North and South there is "the softening effect on the male character of a woman's influence" (Bergmann, 134), Lodge's novel works exactly the other way round. Through his numerous positive qualities, Victor, the industrial leader, liberates "the 'liberated' lecturer from the feminist discourse that has held her captive" (Björk 1993, 124). Thus, it is the female academic who becomes more human, or, to put it differently, who is sexualized, tamed and domesticated. In addition to this, it is in keeping with the discursive logic of Nice Work that Robyn owes the financial and professional security she gains towards the end of the novel to men only - namely Morris Zapp, her Australian uncle, Charles and Philip Swallow - and that she solely invests in male-dominated systems such as free entrepreneurship and British universities (cf. Eagleton 1988, 99 ff.; Wennö 2000, 28).

\section{The Creation of Laughter and the Comic}

Notwithstanding their misogynist subtext and their overtly sexist jokes and stereotypes, Lodge's novels are widely interpreted as being light-hearted, inoffensive and funny. One reason why this is the case is probably Lodge's abundant use of typically 'mainstream' features of comedy, such as the

8 Cf. "Once you realize there is nothing outside the text, you can begin to write it yourself" (NW, 362). 
obligatory happy ending, satire, mild irony, the repeated use and exaggeration of stereotypes and the intervention of "the unexpected". Whether we consider the unexpected change of perspective or the unexpected inversion of norms, they both tend to increase the sense of humour on the part of the reader, for example when Professor Swallow has to use his own lecture notes as toilet paper during his adventure in Turkey ( $S W, 216)$, when he survives a plane crash and starts his absolutely implausible love story with Joy Simpson (cf. Salter 1989, 48) or when - during a conference in Jerusalem he, "his arm round Joy's waist" (SW, 343), accidentally meets his son "Ullo, our Dad" ( $S W, 344)$ - and is virtually 'propelled' out of his romance and back into 'kitchen sink drama', i. e. quotidian greyness with his wife Hilary.

If in his Poetics Aristotle describes the phenomenon of something that makes us laugh as being characterized by flaws, distortion and the absence of pain, these notions imply that there is a transgression of norms which, however, is only experienced as funny if it does not cause real harm. And as a matter of fact, although Robyn clearly transgresses the norms of the British University system, of Victor Wilcox's capitalist economy and of a prudish morality system, she is never really made to suffer in the sense of having to risk life or limb. The fact that she has to go through awkward situations, that she is denigrated, stared at and has to experience shame and unease proves that she is mainly punished by laughter, namely the laughter of the other (male) protagonists, of the narrator and of the reader. In order to achieve this resounding response which is in total accordance with Henri Bergson's thesis that "[n]otre rire est toujours le rire d'un groupe" (5), the text has to create a degree of complicity among the main protagonists, the narrator and the reader concerning the ruling norm. That this complicity undoubtedly exists is demonstrated by the enormous success and - with a few exceptions such as Eagleton, Widdowson or Björk - the largely uncritical, positive and almost naive reception of Lodge's work.

If we consider life as being characterized by a Bergsonian souplesse intérieure, i. e. a certain plasticity and elasticity, it becomes obvious how deficiencies in these qualities such as Robyn's textbook knowledge and 'impenetrable' personality lead to a mechanisation of the individual person, to stiffness and 'inadequacy': "Toute raideur du caractère, de l'esprit et même du corps sera donc suspecte à la société, parce qu'elle est le signe possible d'une activité qui s'endort et aussi d'une activité qui s'isole, qui tend à s'écarter du centre commun autour duquel la société gravite, d'une excentricité enfin" (Bergson 1989, 15). According to Bergson, the comic effect arises from a mechanical repetition across time - from la 'mécanisation de la vie' - in something living and lively and can be considered as a kind of process whereby a human being is turned into an object, a machine, a robot. And this is exactly how the stereotypical Robyn Penrose with her radical views and her missing emotional and sympathetic qualities is characterized 
by the text; a text which repeatedly makes any close reader-identification with Robyn impossible and keeps Victor's - and the narrator's - feminine object of desire at a distance. As a consequence of this, society - be it in the form of Philip Swallow, the narrator or the reader - feels threatened and reacts with a social gesture, namely laughter, in order to re-socialize Robyn and to reintegrate her into society. ${ }^{9}$ And this is exactly what happens in the text, albeit with an intertextual and ironic twist. As has been shown, Victor, the industrial leader, liberates "the 'liberated' lecturer from the feminist discourse that has held her captive" (Björk 1993, 124) in a kind of Lacanian méconnaissance so that Robyn forgets her feminist as well as Marxist convictions and happily invests in Victor's private enterprise. Considering the tight intertextual web Nice Work is part of, the question arises whether we are to take this ending seriously - this would entail one more laugh at the expense of the 'ideologically deluded little girl' who had to undergo a rite de passage to set her convictions right - or whether it mainly functions as a parody of the industrial novel and thereby at least partly suspends its referential function.

On the one hand, Nice Work vehemently emphasizes its almost Victorian realism, on the other hand, it is clearly less about life than about female stereotypes, male fantasies and the literary tradition of the industrial novel from which its happy ending - or endings - is derived. One has to consider that it is Robyn who teaches in her seminars that industrial novels offer their heroines only four options, a legacy, a marriage, emigration or death, and that Nice Work indeed offers three of these solutions - death being per definitionem no option in the comic novel. Given this explicit intertextual dimension which the text repeatedly foregrounds, one could be tempted to interpret the ending of Nice Work as a mere parody of the industrial novel and as a purely intertextual game. This, however, leads to the question in how far - and almost in analogy to Bakhtin's carnivalesque elements ${ }^{10}-$ the satiric and parodistic elements in Nice Work remain authorized by the very

9 If for Bergson laughter helps to reintegrate the individual into society, this implies also that laughter leads to conformity: “Toujours, 'le rire est véritablement une espèce de brimade sociale'. Ce n'est jamais un plaisir purement esthétique. Il comporte 'l'intention inavouée d'humilier, et par là, il est vrai, de corriger'. Il sanctionne beaucoup plus l'insociabilité que l'immoralité" (italics S. H.) (Minois 2000, 481). As has already been shown, especially this last statement is affirmed by the fact that Victor's adultery is neither morally nor symbolically condemned. "Most politically thoughtful commentators wonder [...] whether the 'licensed release' of carnival is not simply a form of social control of the low by the high and therefore serves the interests of that very official culture which it apparently opposes" (Stallybrass and White 1986, 13). Cf. Eagleton 1981, 148: "Carnival, after all, is a licensed affair in every sense, a permissible rupture of hegemony, a contained popular blow-off as disturbing and relatively ineffectual as a revolutionary work of art." Cf. Björk 1993, 89-92; Hutcheon 1989, 99. 
norm they pretend to subvert. Brian A. Connery argues in this context that a) Lodge's novels are not real satires since they lack a corrective aim, that b) they are "inclusive and inescapable, allowing no glimpses of alternative possibilities" (127), c) that they are carnivalesque in the sense that they merely "reify the status quo" (125) and d) that their parodistic elements are "directed at literary conventions and literary antecedents, neither of which are degraded by the parody" (127). Although parody can be understood as "a threatening, even anarchic force, one that puts into question the legitimacy of other texts" (Hutcheon 1989, 100), Lodge's use of parody is characterized by a reinforcing movement that "inscribes the mocked conventions onto itself, thereby guaranteeing their continued existence" (100). Thus, the transgression of Lodge's parody remains strictly controlled. Nice Work ridicules its literary pre-texts but does not really adopt a critical stance towards them and finally inscribes itself into the very same tradition. With the difference, however, that Nice Work not only remains unable to transcend the solutions offered more than a hundred years ago, ${ }^{11}$ it even falls short of them. In stressing the ironic intertextual dimension of the ending, i.e. the almost simultaneous parading of three happy endings typical for the Victorian novel, Nice Work can be read as a rather conservative intertextual game that reaffirms the traditional literary canon (cf. Björk 1993, 112f., 119). If Eagleton has called this kind of ending "a remarkably hollow affair, jarringly divergent from the novel's previous realism" (1988, 101), we should nevertheless note that the parodistic elements neither suspend the "metonymic" or "realistic mode" (Lodge; Björk 1993) of Nice Work nor do they revoke Robyn's political engagement in favour of a capitalist system. ${ }^{12}$ Analogous to the functioning of the "comic mode" as a ploy to cover sexist or misogynist tendencies, the supposedly dialogical principle of Lodge's novel with its almost postmodern carnivalesque and metatextual elements serves as camouflage for a considerable dose of conservatism. ${ }^{13}$

11 Wennö $(2000,29)$ has called the ending " riddled with contradiction"” and "the message of the novel [...] not quite as clear as the resolution suggests".

12 "[I]n a kind of double bluff, the novel generates Gaskellian expectations, goes on to undermine them, and then partly fulfils them. Gaskell's sexual resolution must be rejected [...] but the liberal's material support for capitalism is perfectly acceptable. Or if Nice Work is being ironic about Robyn's final complicity with the system, then this is just another dig at her pseudo-politics" (Eagleton 1988, 101). Cf. Lerner, who states that "in the end Robyn's position seems to me completely undermined" (1988, 38).

13 "The ideological implication is conservative: Trust in the restorative powers of the system (the economic) and by implication, in the power of the individual" (Wennö 2000, 29). Cf. Wolf: Lodge's “message [in Nice Work] is nevertheless no 'muddle'. It is a message which in its elements - systems as order and affirmation of existing institutions - has even more conservative overtones than the ideas underlying Lodge's previous novels" $(1992,38)$. 
Whereas Eagleton (1988) compares Robyn to Margaret Hall and argues that Nice Work "reveals over a century and a half later how little things have changed" (99), Björk even speaks of regression when she states that contrary to her literary precursors, Robyn is not even able to free herself "from contemporary dominant discourses" but "rejects a 'feminist' discourse only to adopt the dominant male discourse" $(1993,124) .{ }^{14}$ Moreover, no matter how often Lodge's 'dialogical novel' refers to E. M. Forster's slogan "Only connect", it finally fails to make town and gown, the workers and the students communicate: "There is no overt arrogance on the students' part, or evident resentment on the young gardener's, just a kind of mutual, instinctive avoidance of contact. Physically contiguous, they inhabit separate worlds" (NW, 384).

\section{Affirmation with a Difference}

Nice Work can be read as a conservative and 'pre-emptive' novel which uses laughter as a prophylaxis to revolution. Towards the end of the book, the 'Old Boys Network' of the Swallows, Zapps and Wilcoxes stays in power while Robyn is allowed a limited subversive influence by becoming part of the modified conservative framework which the novel ultimately reaffirms. But if on one level the answer to Wilcox's question "Who pays?" is Robyn Penrose, ${ }^{15}$ not to mention Marjorie, it is on a more abstract level the text itself which pays a high price for a blindness and partiality it remains unaware of. After all, it is not only Robyn who falls prey to méconnaissance: if Lodge sees in Nice Work an emancipatory novel with a happy ending, he seems to be caught in a traditional patriarchal discourse at least as much as Robyn is caught in feminist theory.

Since it is exactly this patriarchal and probably un- or subconscious functionalisation of femininity which constitutes the deep structure of Nice Work, what on first glance may seem to be a "warm comic glow" (Financial Times $)^{16}$ turns out to be an unavowed and at times even vicious satire

14 Contrary to Björk, one is tempted to play devil's advocate and argue that Robyn's constant entanglement in discourses is less a regression than a demonstration that - in analogy to Malcolm Bradbury's novel The History Man - even for Nice Work there is ultimately nothing outside discourse. This kind of reading would, of course, have to completely ignore the predominant liberal-humanist line of argument that pervades the novel in its totality.

15 Robyn's function is not only to rebuild the patriarchal core family and to strengthen capitalism, but also to consolidate the British University system. Therefore she must refuse an offer to apply for a well paid tenure track position in the United States and is 'rewarded' with another one year contract at Rummidge University.

16 Blurbs on the cover of the Penguin Edition 1989. 
on femininity and post-structuralism. But, as so often with Lodge, this is only one side of the coin: if, as Anton C. Zijderveld does, and leaving aside Bergson, we consider humour as a game with the institutionalized, traditional and differentiated values and norms of a given society, the novelist Lodge can be called a homo ludens who playfully reshuffles the components of the surrounding textual as well as extra-textual nomos, reversing the established order of opposites. Of course, the ambiguities and incongruities which Nice Work portrays only constitute a mirthful interlude and not a rebellion or a revolution, but what is significant is that the condescending laughter about Robyn, the radical feminist, - a kind of laughter fuelled by the self-perceived superiority of the other protagonists, the reader and a paternalist narrator - is accompanied by a sympathetic and affirmative laughter with Robyn - and about the institutions - when she gradually uncovers the deficiencies of the ruling system just as Nice Work pretends to reveal the datedness of its pre-texts.

Concentrating on the level of the histoire, we can state that Lodge's novel manages to make us laugh about both the poststructuralist and feminist camp on the one side and about the patriarchal, traditional British University system and British industry on the other; about the feminine object of desire and about the male subject who desires. Lodge's campus novels use laughter in at least a twofold way: to de-radicalize and to re-integrate 'awkward customers' such as Robyn into society and simultaneously to slowly modify and change this society itself. ${ }^{17}$ The eventual outcome of this double comic of denigration is a heavily biased compromise (Wolf 1992, 39; Lodge in: Haffenden 1985, 157) with Robyn being subsidized but essentially footing the bill. ${ }^{18}$ The laughter which Nice Work sparks off is not really dangerous or subversive but well controlled and ultimately restorative of the social as well as of the literary system; restorative, however, with the slight but significant difference that the ruling order is not only reaffirmed but also modified since Lodge's trilogy of campus novels - and especially Nice Work - cannot repress its knowledge that the ruling norm, as represented by a deaf, tired "and slightly seedy" (NW, 63) Philip Swallow or a highly competitive, single-minded businessman such as Victor Wilcox, has at least to a certain degree become as inadequate and obsolete as the parodied solutions of the $19^{\text {th }}$-century industrial novel and maybe even as Nice Work itself.

17 As has been shown, these modifications are never radical but consensual and ultimately even reinforce sexual stereotypes in the same way as parodies tend to re-confirm their pre-texts.

18 Lodge contends that Victor suffers more than Robyn but concedes: "I suppose the joke is on Robyn” (Lodge in: Díaz Bild 1989, 266). 


\section{Works Cited}

Lodge, David. 1965 (121983). "An Afterword”. The British Museum is Falling Down. London: Penguin. 163-74.

Lodge, David. 1975 (241978). Changing Places. New York/London: Penguin.

Lodge, David. 1984 ( $\left.{ }^{4} 1991\right)$. Small World. New York: Warner Books.

Lodge, David. 1988 (71989). Nice Work. London: Penguin.

Lodge, David. 1988. "Thinking about Women: Eleven Male Authors Discuss the Impact of Feminism on Their Writing". Times Literary Supplement 3-9 June 1988: 612-15.

Lodge, David. 1992. The Art of Fiction: Illustrated from Classic and Modern Texts. Harmondsworth: Penguin.

Lodge, David. 1993. “Adapting Nice Work for Television”. Novel Images: Literature in Performance. Ed. Peter Reynolds. London: Routledge. 191-203.

Acheson, James. 1991. "The Small Worlds of Malcolm Bradbury and David Lodge”. The British Novel and Irish Novel since 1960. Ed. James Acheson. Houndmills and London: Macmillan. 78-92.

Antor, Heinz. 1996. Der englische Universitätsroman. Heidelberg: Winter.

Bergmann, Helena. 1979. Between Obedience and Freedom: Woman's Role in the Mid-Nineteenth Century Industrial Novel. Göteborg: Acta Universitatis Gothoburgensis.

Bergson, Henri. 1989. Le Rire. Paris: Quadrige.

Bill, Brigitte \& Peter Naus. 1992. "The Role of Humor in the Interpretation of Sexist Incidents”. Sex Roles: A Journal of Research 27: 645-64.

Björk, Eva Lambertsson. 1993. Campus Clowns and the Canon: David Lodge's Campus Fiction. Stockholm: University of Umeå Dissertation.

Böhm, Rudolf. 1994. "Universität und Industrie: 'Zwei Nationen' in David Lodges Nice Work". Das Natur/Kultur-Paradigma in der englischsprachigen Erzählliteratur des 19.u. 20. Jahrhunderts. Ed. Konrad Gross et al. Tübingen: Narr. 222-36.

Borch-Jakobson, Mikkel. ${ }^{2}$ 1994. Lacan. The Absolute Master. Stanford: Stanford UP.

Burton, Robert. 1994. "Standoff at the Crossroads: When Town Meets Gown in David Lodge's Nice Work”. Critique 35: 237-43.

Cachin, Marie-Françoise. 1992. "Nice Work de David Lodge: Jeu de société ou jeu d'écriture". Etudes britanniques comtemporaines 0: 123-32.

Connery, Brian A. 1990. "Inside Jokes: Familiarity and Contempt in Academic Satire”. University Fiction. Ed. David Bevan. Amsterdam: Rodopi. 123-37.

Díaz Bild, Aída. 1989-90. "On Realistic Fiction and Bakhtin: A Conversation with David Lodge”. Revista Canaria de Estudios Ingleses 19-20: 265-76.

Drexler, Peter. 2001. "The Novelist Still at the Crossroads: Überlegungen zum Wechselverhältnis von Theorie und Praxis in David Lodges neuerem Werk". Erzählen und Erzähltheorie im 20. Jahrhundert. Ed. Jörg Helbig. Heidelberg: Winter. 341-56.

Eagleton, Terry. 1981. Walter Benjamin: Towards a Revolutionary Criticism. London: Verso.

Eagleton, Terry. 1988. “The Silences of David Lodge”. New Left Review 172: 93 102.

Freud, Sigmund. 1960. Jokes and their Relation to the Unconscious. The Standard Edition. Transl. and ed. by James Strachey. New York/London: Norton. 
Haffenden, John. 1985. Novelists in Interview. London: Methuen.

Hidalgo, Pilar. 1984. "Cracking the Code: The Self-Conscious Realism of David Lodge". Revista Canaria de Estudios Ingleses 8: 1-12.

Horlacher, Stefan. 2006. Masculinities. Konzeptionen von Männlichkeit im Werk von Thomas Hardy und D. H. Lawrence. Tübingen: Narr.

Hutcheon, Linda. 1985. A Theory of Parody: The Teachings of Twentieth-Century Art Forms. New York: Methuen.

Hutcheon, Linda. 1989. “Modern Parody and Bakhtin”. Rethinking Bakhtin: Extensions and Challenges. Ed. Garry Saul Morson and Caryl Emerson. Evanston: Northwestern UP. 87-103.

Irigaray, Luce. 1974. Speculum de l'autre femme. Paris: Les Editions de Minuit.

Irigaray, Luce. 1977. Ce sexe qui n'en est pas un. Paris: Les Editions de Minuit.

Kristeva, Julia. 1986. "Stabat Mater". The Kristeva Reader. Ed. Toril Moi. New York: Columbia UP. 160-86.

Kühn, Thomas. 1992. "Exploding the Myth of English University Life: Observations on Some Contemporary English University Novels”. Anglistik \& Englischunterricht 46/47: 155-78.

Kühn, Thomas. 2002. Two Cultures, Universities and Intellectuals: Der englische Universitätsroman der 70er und 80er Jahre im Kontext des Hochschuldiskurses. Tübingen: Narr.

Lerner, Laurence. 1988. “The Return of the Signified”. Spectator 24 Sep. 1988: 37-38.

Mallet, Phillip. 1989. "Sexual Ideology and Narrative Form in Jude the Obscure". English 38: 211-24.

Minois, Georges. 2000. Histoire du rire et de la dérision. Paris: Fayard.

Morace, Robert. 1989. The Dialogic Novels of Malcolm Bradbury and David Lodge. Carbondale: Southern Illinois UP.

Ommundsen, Wenche. 1990. "Sin, Sex, and Semiology: Metafictional Bliss and Anxiety in the Novels of David Lodge". Aumla: Journal of the Australian Universities Language and Literature Association 73: 123-40.

Salter, Mary Jo. 1989. “Only Connect”. New Republic 18/25 Sep. 1989: 46-52.

Stallybrass, Peter and Allon White. 1986. The Politics and Poetics of Transgression. London: Methuen.

Wennö, Elisabeth. 2000. "Work, Love and Gender in David Lodge's Nice Work". Moderna Språk 94: 19-30.

Widdowson, Peter. 1984. "The Anti-History Men: Malcolm Bradbury and David Lodge”. Critical Quarterly 26.4: 5-32.

Winston, Robert P. \& Timothy Marshall. 2002. "The Shadows of History: The 'Condition of England' in Nice Work". Critique 44: 3-22.

Wolf, Werner. 1992. "The Fiction of David Lodge in the Eighties - Discontent with Life and Literature Expressed from a Moderate, Liberal and Undogmatically Christian Point of View". Anglistik \& Englischunterricht 48: 19-42.

Zijderveld, Anton C. 1968. "Jokes and their Relationship to Social Reality". Social Research 35: 2: 286-311.

Zijderveld, Anton C. 1983. "Trend Report: The Sociology of Humour and Laughter". Current Sociology 31.3: 1-100. 